\title{
A Lexical-Chunk Based Study of Business English Correspondence Writing
}

\begin{abstract}
LEI Chao
Zhoukou Normal University, Zhoukou, China

Lexical chunks are multiword lexical phenomena that exist somewhere between the traditional poles of lexicon and syntax, conventionalized form/function composites that occur more frequently and have more idiomatically determined meaning than language that is put together each time. Lexical chunks theory supports the development of syntactic rules, helps learners to achieve idiomaticity and appropriateness of business expressions, and benefits successful business communication. Through the study of lexical chunks, the major findings are that possibility of lexical chunks in business English correspondences is relatively high, and among factors influencing discourse coherence, lexical chunks are the main point that has already attracted much attention of users. Based on the study, some pedagogical suggestions are provided in business English correspondence writing class.
\end{abstract}

Keywords: lexical chunks, business English correspondence, writing class

\section{Introduction}

In recent years, linguists and foreign language teachers are becoming increasingly aware of the importance of lexical chunks in language learning and teaching. Many linguists have made a lot of studies on the lexical chunks theory. Lexical chunks theory supports the development of syntactic rules, helps learners to achieve idiomaticity and appropriateness of expressions. The most important principle of lexical approach is that language consists of grammaticalized lexis — not lexicalized grammar (Adamson, 2007, pp. 66-67). Business English letters are the main ways to communicate in business; therefore, business English letter's quality decides the success or failure of a business deal. Owing to the important role of lexical chunks in language acquisition and the practical value of English business letter, it is essential to study the characteristics of the use of lexical chunks in business English letter. English language learners should pay more attention to lexical chunks and make them fully used. For English language teachers, this study may provide them with the use of lexical chunks in business English letters writing class, and facilitate their teaching in class. This paper investigates the characteristics of the use of lexical chunks in business English letters on the basis of Hattingen and Decarrico's (2010, p. 97) four types criterion, tries to probe the rule of business letters writing, and proposes the constructive way for teachers in business correspondence writing class.

\section{Lexical Chunks}

\section{Definition of Lexical Chunks}

According to Becker (2011, p. 39) and Decarrico (2009, p. 15), lexical chunks are lexical phrases in

LEI Chao, associate professor, M.A., The Foreign Languages School, Zhoukou Normal University. 
languages with length loaded with pragmatic function. "They are multiword lexical phenomena that exist somewhere between the traditional poles of lexicon and syntax, conventionalized form/function composites that occur more frequently and have more idiomatically determined meaning than language that is put together each time" (Decarrico, 2009. p. 12). These phrases include short, relatively fixed phrases such as long ago, or longer phrases or clauses such as if I X, then I $Y$; the _ er X, the _ er $Y$, each with a fixed, basic frame, with slots for various fillers ( a day ago; a week ago; the bigger $X$, the smaller $Y$; the older you are, the wiser you are).

\section{Classification of Lexical Chunks}

Considering that lexical chunk is the combination of function and form, the author adopts the classification made by Hattingen and Decarrico (2010, p. 97). They classify lexical chunks into four categories:

(1) Poly words: Poly words are short phrases which are used as individual lexical items. They can be both canonical and not canonical. They do not allow variability. They are continuous. For instance: hold your horses; not on your life; as it were; I'll say; what on earth?;

(2) Institutionalized expressions: "Institutionalized expressions are lexical phrases of sentence length, usually functioning as separate utterances. They are mostly canonical. They are invariable. They are mostly continuous" (Fernando, 2011, p. 103). The latter two respects are very similar to poly words. Institutionalized expressions are proverbs, aphorisms, aphorisms, and formulas for social interaction, which are used for quotation, allusion, or direct use, For instance: give me a break; there you go; be that as it may; long time no see, and so on;

(3) Phrasal constraints: Phrasal constraints are short-to-medium-length phrases. They can be both canonical and not canonical. They allow variation of lexical and phrasal categories (NP, VP, Adj P, Adv P, N, $\mathrm{V}$ Adj, etc.). They are continuous. For example: good _ (greeting) good morning, good afternoon, good evening; dear _ (greeting) dear First name, dear Title + Last name; to make a long story (relatively) short (summarizer); the _ er the _ er (comparator) the sooner the better; the busier the happier;

(4) Sentence builders: Sentence builders are lexical phrases that provide the framework for whole sentences. They contain slots for parameters or arguments for proverbs, aphorisms, and formulas for social interaction, which are used for. They are both continuous and discontinuous. For example: I think (that) $X$ (assertion); Not only was her mother injured in the accident, but also her father; the sooner all this work is finished, the sooner we will all be able to go home, and so on.

Different expressions and words can perform different functions, because proverbs, aphorisms, and formulas for social interaction, which are used for implications. Commendatory terms and positive words can create a pleasant tone and can help to produce a desirable psychological effect on readers. Moreover, in some situation, like business environment, commendatory terms can play a significant role in helping business people to reach agreement; on the contrary, derogatory words would make good into bad, create unnecessary misunderstanding, and obstacle among people or organizations.

\section{Lexical Chunks in Business Letter}

Business English letter is used in business transactions to promote international trade relationship and to transform as a form of essential communication and written document. Business English correspondence takes various forms in the business activities, such as business e-mails and business faxes. They serve the purposes of inquiring information, offering, giving a reply, negotiating, proposing, claiming and adjusting, ordering goods, 
selling products, and also building good relationships, etc. Business English letter is indispensable to business communication. In order to see the lexical chunks clearly in the business letters, let's see one sample letter about payment and the coverage of risks in business.

\section{Dear Sirs,}

Thank you for your letter of December 6 and your L/C No. TK309 for RMB25,000 issued by the Bank of Singapore, advised through the Bank of China, Hong Kong.

On going through the stipulations of your credit, we regret to find that in addition to FPA and War Risk, you require insurance to cover TPND and SRCC which were not agreed upon by both parties during our negotiations at the First Beijing International Fair. Under the ordinary circumstance, no loss or theft of such merchandise as mild steel flat bars is likely to occur during transport or after arriving at its destination. Therefore, it is our practice to cover FPA for such commodity. Since you desire to have your shipment insured against TPND, with regard to SRCC, we wish to state that the People's Insurance Company of China, from now on, accepts this special coverage and will fall in with the usual international practice. We hope you will see your way to arrange with your bank for an amendment to your L/C. We assure you that as soon as your amendment reaches us, we shall of course, make the necessary arrangement for the shipment.

Yours faithfully

In the above, all the underlined words and phrases are lexical chunks in according to the definition.

Next the author selects four types of English business letters which are shipment, inquiry, order, and complaint. Based on Hattingen and Decarrico's (2010, p. 97) four types of categorization, the use of lexical chunks in English business letters is analyzed. The process of identifying and classifying lexical chunks is made by hand. In the process of that, lexical chunks repeating several times in one business letter are counted as one lexical chunk.

Table 1

The Use of Lexical Chunks in Inquiries and Offers

\begin{tabular}{|l|l|}
\hline Total words & 589 \\
\hline Average words & 103 \\
\hline Poly-words & 16 \\
\hline Institutionalized expressions & 11 \\
\hline Phrasal constraints & 31 \\
\hline Sentence builders & 24 \\
\hline Total lexical chunks & 58 \\
\hline No. of words in lexical chunks & 346 \\
\hline
\end{tabular}

\section{Table 2}

The Use of Lexical Chunks in Making Counter-Offers

\begin{tabular}{|l|l|}
\hline Total words & 1024 \\
\hline Average words & 289 \\
\hline Poly-words & 45 \\
\hline Institutionalized expressions & 66 \\
\hline Phrasal constraints & 89 \\
\hline Sentence builders & 56 \\
\hline Total lexical chunks & 201 \\
\hline No. of words in lexical chunks & 278 \\
\hline
\end{tabular}


Table 3

The Use of Lexical Chunks in Shipment

\begin{tabular}{|l|l|}
\hline Total words & 645 \\
\hline Average words & 231 \\
\hline Poly-words & 76 \\
\hline Institutionalized expressions & 81 \\
\hline Phrasal constraints & 12 \\
\hline Sentence builders & 8 \\
\hline Total lexical chunks & 132 \\
\hline No. of words in lexical chunks & 105 \\
\hline
\end{tabular}

Table 4

The Use of Lexical Chunks in Complaint

\begin{tabular}{|l|l|}
\hline Total words & 784 \\
\hline Average words & 87 \\
\hline Poly-words & 108 \\
\hline Institutionalized expressions & 45 \\
\hline Phrasal constraints & 201 \\
\hline Sentence builders & 12 \\
\hline Total lexical chunks & 21 \\
\hline No. of words in lexical chunks & 310 \\
\hline
\end{tabular}

\section{Findings From the Figure}

In Table 1 “The Use of Lexical Chunks in Inquiries and Offers”, among 589 words, the number of four structural categories of lexical chunks poly-words, institutionalized expression, phrasal constraints, and sentence builders are 16, 11, 31, and 24 respectively. And the total lexical chunks are 58. In Table 2 "The Use of Lexical Chunks in Making Counter-Offers", among 1,024 words, the number of four structural categories of lexical chunks poly-words, institutionalized expression, phrasal constraints, and sentence builders are 45, 66, 89, and 56 respectively. And the total lexical chunks are 201. In Table 3 "The Use of Lexical Chunks in Shipment", among 645 words, the number of four structural categories of lexical chunks poly-words, institutionalized expression, phrasal constraints, and sentence builders are 76, 81, 12, and 8 respectively. And the total lexical chunks are 132. In Table 4 "The Use of Lexical Chunks in Complaint", among 784 words, the number poly-words, institutionalized expression, phrasal constraints, and sentence builders are 108, 45, 201, and 12 respectively. And the total lexical chunks are 21.

Through the analysis of the four types of English business letters, it shows that the characteristics of the use of the four structural categories are almost the same. The number of sentence builder is the biggest, followed by institutionalized expressions, poly-words, and phrasal constraints. According to Bollinger (2013, p. 129), this sequence in using lexical chunks might owe to the different degrees of variability and discontinuity of four categories of lexical chunks. The most variable lexical chunks are sentence builders which allow great variation and are used more frequently than other three categories. English business letter must be concise and do not need those words to polish the article. Therefore, institutionalized expressions are rarely used in it.

It is found from the above study that among the four structural categories of lexical chunks, in letters both from foreign trade company and from students, it is sentence builders that dominate in English business letters 
followed closely by phrasal constraints. It can be presumed that sentence builders and phrasal constraints contribute most to a good business letter in that there are significant differences of the use of sentence builders and phrasal constraints between high-rated and low-rated writings.

\section{Application of Lexical Approach to Business English Correspondence Writing Class}

Lexical chunks are important parts of language that include phrases and whole sentences, so the learners have to remember more words. Using lexical chunks in writing can avoid inappropriate use in terms of registering and enhancing written fluency. That is to say, the main functions of lexical chunks in writing are to ease the language processing and to facilitate language production. In the following, some representative lexical chunks selected from the framework of their function are presented in detail, which is very useful in business letter writing class (CHANG, 2015, p. 152).

(1) Opening: begins with a salutation, usually dear [Title] + Last name, often followed by a phrase referring to what promoted the letter: thank you for/we are in receipt of your letter (of DATE) (requesting X), then moves quickly into the main purpose of the letter by nominating the topic;

(2) Body: nominates topics with such lexical phrases as: this is/I am happy/regret to inform you that X; in reference to__; your letter (of DATE) (in which X). As mentioned above, phrases signaling discourse purpose are more formal and explicit than those used in informal letters. For example, agreement is likely to be expressed by a phrase such as $I /$ we are in (total) agreement with $X$; recommendation by let me advise/suggest/recommend that you $X$;

(3) Closing: usually contains extended formulas that signal imminent closing (please let me know what you think about all of this); I'll be happy to answer any questions you (might) have (about all of this/the above); recommendation by let me suggest/advise/propose that you X be pleased to answer at your convenience, etc.), actual closing with such phrases as with best regards/wishes, sincerely/respectfully/very truly yours.

As we all know, it is not easy to memorize vocabulary, practice the grammar exercise, and understand the meaning, so writing is the hardest skill of the four basic skills in foreign language learning. Writing needs integrating what you have learned and outputting things creatively. It is the most complex in the four language skills. Besides, writing is viewed as double roles: It can be used to reinforce other language skills and serves as a significant way of communication between people.

When in business English letters writing class, it is proposed that lexical approach is a new method to improve writing ability. If teachers can arouse the students' awareness of lexical chunks, and guide them to practice the chunks according to situations, it is feasible to remind students of chunks in their brains. When the lexical chunks are memorized as memory units, it is high time for the students to write using the chunks.

Lexical chunks can help students catch the theme of composition, organize the structure of a composition effectively, and accelerate writing speed, that is, they may use less time on working out how to open, how to shift topic, how to summarize, etc. Therefore, catching lexical chunks of structural organization is necessary to start a good composition. Carter (2013, p. 131) offered his own teaching method as for how to teach writing with lexical chunks.

At the beginning of language learning, let students practice sentence completion exercises, and memorize the invariable or less variable phrases. Teachers can explain the variations of these phrases as students progress. Then, make the basic outline of written discourse clear. Soon afterwards, teachers see through it 
section by section, introducing them to phrases that are used in common to express the function of each section. Thus, the lexical phrases can be systematically presented. And by this time, students should start to practice piecing all phrases together, discoursing effective methods of joining lexical chunks to finish a composition.

According to lexical approach, the most important step is to make students aware of chunks, and offer opportunities to learners to identify, organize, and record chunks. But to identify, organize, and record chunks is not easy for students, especially for the beginners. Therefore, various activities should be adopted in writing class as follows:

(1) First and second language comparisons and translation-chunk for chunk, rather than word-for-word-aiming at raising language awareness;

(2) Repetition and recycling of activities, such as summarizing a text orally one day and again a few days later to keep words and expressions that have been learned active;

(3) Guessing the meaning of vocabulary items from contest;

(4) Noticing and recording language patterns and collocations;

(5) Working with dictionaries and other reference tools;

(6) Working with corpuses created by the teacher for use in the classroom or accessible on the Internet so as to research word partnerships, preposition usage, style, and so on (Lewis, 2007, p. 111).

From the above, it is feasible for teachers to introduce lexical approach to business English writing class, through which students can harvest a lot.

\section{Conclusion}

In this paper, the author adopts quantitative and qualitative approaches to study the features of the use of lexical chunks in business English letters. From the analysis of the sample letters, high usage of lexical chunks in business correspondences is evident. The major findings are found that possibility of lexical chunks in business English correspondences is relatively high. Traditionally, the learners do not realize the importance of lexical chunks in writing the business letters. Lexical chunks can help them put new words into real use. So it is very important for teachers to input lexical chunks into students instead of single words. The use of lexical chunks can facilitate writings and help them improve business English writing ability. These lexical chunks can reduce students' burden of language processing and increase fluent and logical writing (Firth, 2011, p. 301). The results of this study hope to raise people's consciousness of lexical chunks in foreign English teaching and learning; it also offers some suggestion for vocabulary acquisition and language teaching. The author wishes the study can make contributions to both the theoretical and practical aspects on lexical features of business English letters and hopes to enrich the studies of lexical chunk features and help the learners to write excellent business English letters more easily.

\section{References}

Adamson, B. (2007). Vocabulary teaching and learning. Comparative Education Review, 10, 66-67.

Becker, J. (2011). The phrasal lexicon. In Theoretical issues in natural language processing. Cambridge: Bolt, Bernanke and Newman.

Bollinger, D. (2013). Meaning and memory. Forum Linguisticum, 1, 129.

Carter, D. (2013). Some propositions about ESP. The ESP Journal, 2, 131-137.

CHANG, Y. T. (2015). Business English report writing. Beijing: Foreign Language Press. 
Decarrico, J. S. (2009). Lexical phrases and language learning. Oxford: Oxford University Press.

Fernando, C. (2011). Idioms and idiomaticity. Shanghai: Shanghai Foreign Language Education Press.

Firth, R. (2011). Papers in linguistics 2000-2010. London: Oxford University Press.

Hattingen, P., \& DeCarrico, J. S. (2010). Lexical phrases and language. Cambridge: Cambridge University Press.

Lewis, R. (2007). The second language writing. London: Allen \& Unwin. 